\title{
СИБИРСКАЯ НЕОАРХАИКА
}

Галыгина Ольга Михайловна

ИскусствовеА, Президент

БАаготворительного фонАа

«Современное искусство Сибири»,

член ВТОО «Союз художников России».

Россия, г. Омск.

Sibgal@rambler.ru

\section{Аннотация}

Автор статьи представляет обзор Международного художественного проекта «Сибирская неоархаика» (2014, Новосибирск).

КАючевые слова: искусство Сибири, неоархаика, северный изобразительный стиль, этноархаика, археоарт, археоавангарА, выставка, художественный проект.

\section{Библиографическое описание Амя цитирования:}

Галыгина О.М. Сибирская неоархаика // Искусство Евразии. - 2015. - № 1 (1). C. 135-138. DOI: 10.25712/ASTU.2518-7767.2015.01.011. [ЭАектронный ресурc] URL: https://readymag.com/u50070366/416035/26/

12 ноября 2014 года в Новосибирском государственном художественном музее состоялся МежАународный художественный проект «Сибирская неоархаика».

БАаготворительный ФонА «Современное искусство Сибири» преАставил его в рамках Всероссийской научной конференции (с межАународным участием) «Архаическое и траАиционное искусство Сибири: проблемы научной и художественной интерпретации». В марте 2015 г. проект продолжиц работу в Новокузнецком художественном музее. Кураторы выставки: ОАьга Галыгина (Новокузнецк), ВАадимир Чирков (Омск).

В выставках приняли участие: Аариса Пастушкова (живопись) из Барнаула; Сергей Аыков (живопись, графика) из Горно-Алтайска; Виталий Смагин (объект) и АлексанАр Алсаткин (Аекоративно-прикладное искусство) из Иркутска; Сергей Ануфриев (объект, цифровая печать), Валерий Сысоев (скульптура), Николай Рыбаков (живопись) из Красноярска; Александр Суслов (живопись, графика) из Новокузнецка; Аанила Меньшиков (живопись, графика) из Новосибирска; Евгений Аорохов (живопись) и Татьяна Колточихина (объект) из Омска; Сергей Аазарев (живопись, графика) из Томска; ВАадимир Бугаев (цифровая печать, видеоарт) из Ханты-Мансийска; Амитрий Будажабэ (скульптура), Зандан Аугаров (скульптура) и Евгений Болсобоев (графика) из УАан-УАэ. Среди зарубежных участников: Александр Бобкин (графика) и Аюдмила Бессонова (текстиль) из Голмандии; Вирле Румс (Gicleeprint), Кристоф Меул (печать натуральными пигментами) и Александра Галыгина (графика, текстиль) из Бельгии. 
Также на выставке был представлен каталог, продемонстрированы документальный фильм «Сибирская неоархаика», художественная колмекция моделей одежды новокузнецких модельеров Е. Баскаковой и О. Аевченко и ювелирная колмекция А. Выпова.

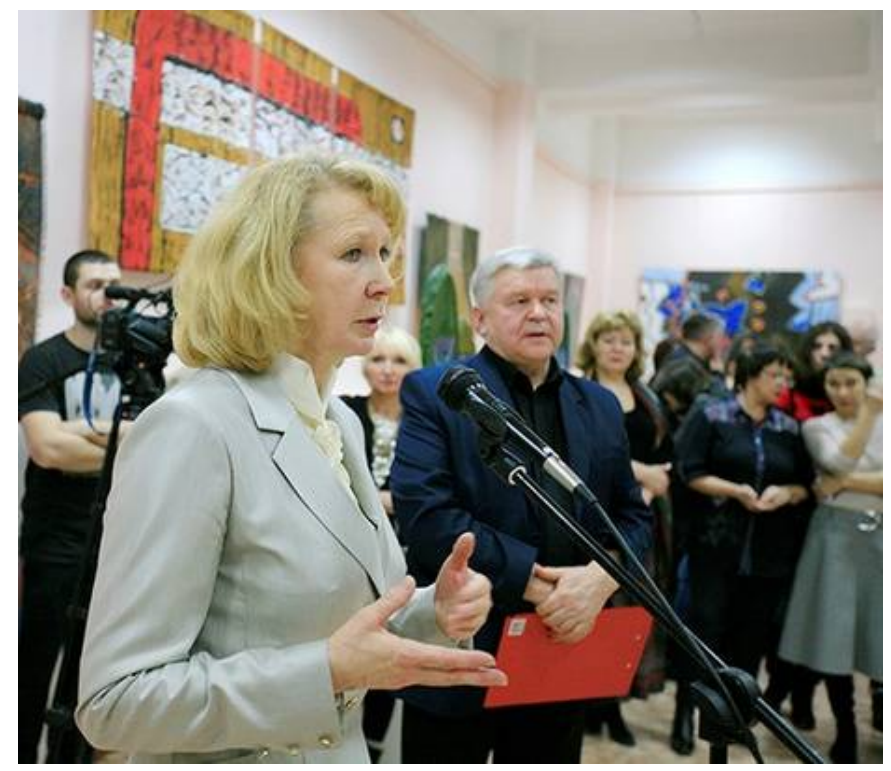

Рис. 1. Гальгина Ольга Михайловна, куратор въгставки «Сибирская неоархаика».

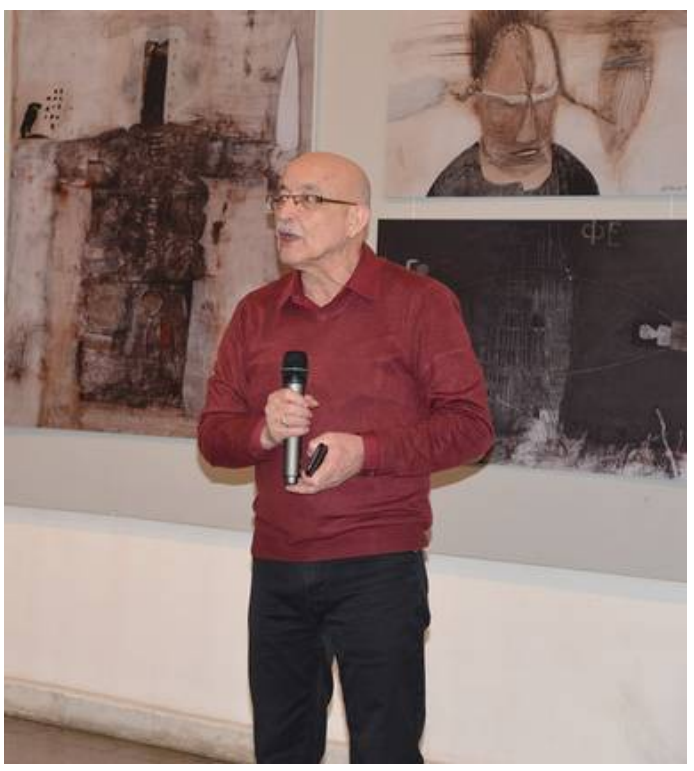

Рис. 2. Выступает Владимир Чирков, Омск.

Сибирская неоархаика как художественное направление в современном искусстве России начала формироваться еще в конце XIX - начале XX века в Сибири (А^тай, Томск, Иркутск) под названием «сибирский стиль». В 1920-егоды в Иенинграде в Институте народов Севера получило свое развитие как «северный изобразительный стиль». Возобновление интереса к нему наблюдалось снова в Сибири в творчестве шестилесятников, а в последнюю четверть ушедшего века приобрело всесибирский характер, сопровождаемый различными определениями: этноархаика, археоарт, археоавангарА.

Сибирская неоархаика носит ярко выраженный экстерриториальный характер по своей пространственной протяженности (Байкальский регион, Саяно-Енисейская и Хакасо-Минусинская котловины, А^тай, Тыва, Западная Сибирь) и Алительности во времени - без малого целый век.

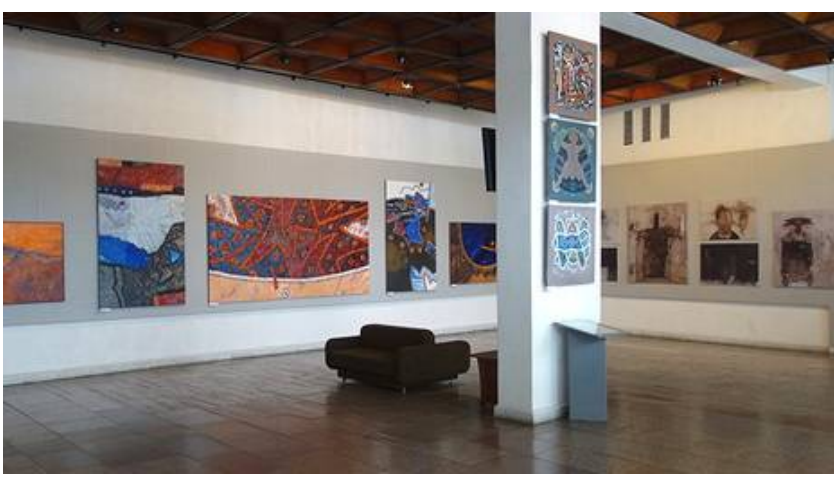

Рис. 3. Экспозичия в Новокузнечке.

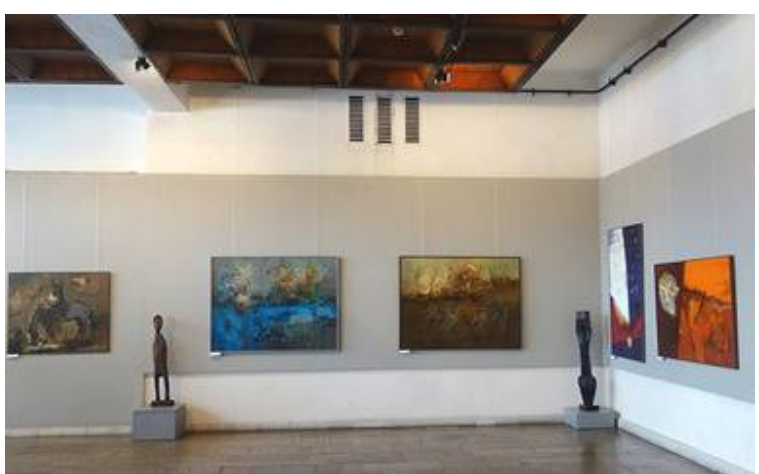

Рис. 4. Экспозичия в Новокузнечке. 
Направление вкцючает в себя художников, ставших крупными именами в отечественном искусстве. Особенностью сибирской неоархаики является то, что это искусство пришло в Сибирь не извне, а было порождено именно Сибирью, то есть направление имеет мощные исторические корни содержательного и формального, пластического, характера. По А.Н. Гумилеву, питающим, порожАающим, кормящим Аандшафтом сибирской неоархаики являются богатейшая история, мифология, природа Сибири, волею безымянных творцов превратившиеся в выдающиеся этнографические, фольклорные, изобразительные памятники. Особенностью этих памятников является то, что в них воплотились образы, связанные с жизнью на земле, продолжением человеческого и животного родов, с физическим и духовным освоением пространства. Это тот мокус, в пространстве которого исторически живет человек Ауховный. Мир в Аревних памятниках предстает единым, целостным, органичным, трепетным. ГАядя на прошедший век, видишь, что актуализация вылающегося наследия этносов Сибири происходила в течение целого столетия и в своих ритмах совпадает с теми временами, когда мировые и отечественные общества и культуры испытывали кризисные явления. Авторы сибирской неоархаики сначала интуитивно, затем

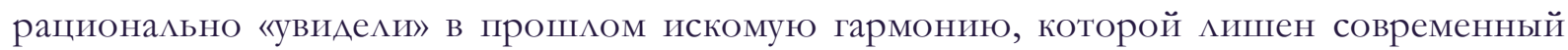
мир. Название выставки, вынесенное в заголовок, - «Сибирская неоархаика» актуа^изирует исторический опыт Ауховности.

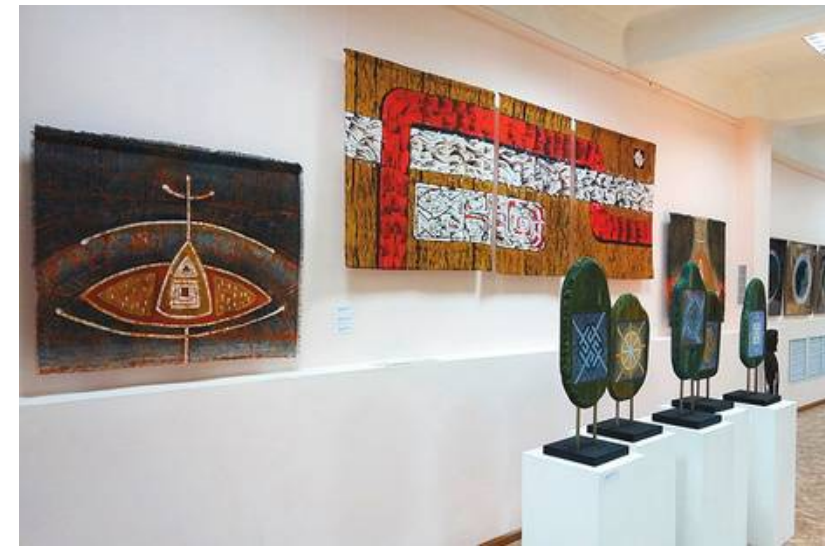

Рис. 5. Работы Татьяны Колточихиной и Сергея Ануфриева.
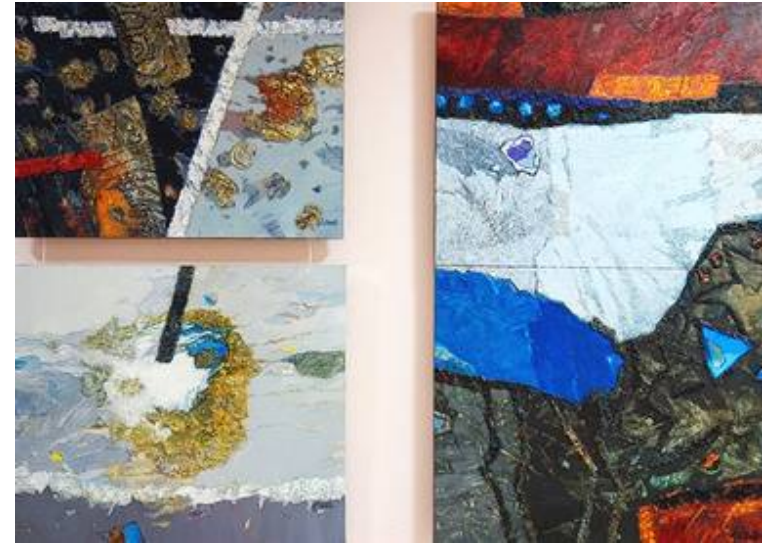

Рис. 6. Экспозичия картин Евгения Аорохова.

Сибирская неоархаика, с художественной точки зрения, представляет огромный познавательный и эстетический интерес. Фактически, это межвидовое искусство: авторы работают в живописи, графике, пластике, керамике, актуальном искусстве. Все ведущие мастера направления в своих цучших произведениях Аемонстрируют тот профессиональный опыт, который органично включает наследие прошлого и язык современного искусства. И именно в этом художественном качестве искусство сибирской неоархаики преАставАяет общекультурный интерес.

Статья поступила в редакцию 14.09.2015 г. 
DOI 10.25712/ASTU.2518-7767.2015.01.011

\title{
SIBERIAN NEO-ARCHAIC
}

Galygina Olga Mikhailovna

Art critic, President of the Contemporary Art

of Siberia Charitable Foundation,

Member of the Union of Artists of Russia.

Russia, Omsk.

Sibgal@rambler.ru

\begin{abstract}
The author of the article presents a review of the «Siberian Neo-Aarchaic» International Art Project (2014, Novosibirsk).

Keywords: art of Siberia, neo-archaic, northern visual style, ethnoarchic, archeoart, archeoavangard, exhibition, art project.

\section{Bibliographic description for citation:}

Galygina O.M. Siberian Neo-Archaic. Iskusstvo Evrazii - The Art of Eurasia, 2015, No. 1 (1), pp. 135-138. DOI: 10.25712/ASTU.2518-7767.2015.01.011. Available at: https://readymag.com/u50070366/416035/26/ (In Russian).
\end{abstract}

Received: September 14, 2015. 